\title{
Relevance of Ethics Program Components in Slovakia
}

\author{
${ }^{1}$ Anna Remišová, ${ }^{2}$ Anna Lašáková, ${ }^{3}$ Zuzana Kirchmayer \\ ${ }^{1,2,3}$ Comenius University in Bratislava, Faculty of Management, Slovakia
}

\begin{abstract}
2016 Research Leap/Inovatus Services Ltd. All rights reserved.

DOI: 10.18775/jibrm.1849-8558.2015.21.3004

URL: $\underline{\text { http://dx.doi.org/10.18775/jibrm.1849- }}$ 8558.2015.21.3004

\section{Keywords:}

Business Ethics;

Ethics Program;

The aim of the article is to examine to what extent can the different formal components of an ethics program of the organization influence ethical thinking of managers. As the main source of information, an extensive empirical research was carried out on a sample of 810 managers working in the Slovak business environment. The authors studied eleven formal elements of the ethics program and found out that all positively referred to the ethical thinking of managers. Thus organizations, in which formal elements of an ethics program are applied, have a greater ability to influence the ethical thinking of managers than organizations, which avoid the respective ethical mechanisms.
\end{abstract}

Managerial Ethical Decision-Making.

\section{Introduction}

Long-term and successful development of business ethics in organizations is linked to the functioning of a sound ethics program. In the period when business ethics began to develop in Slovakia, the notion of organizational ethics program was quite unknown in both the theory and praxis. In Slovak conditions, the business ethics began to develop first as an academic discipline in the 90s of the last century. Its subsequent application in praxis is associated with the transition of the economics based on state ownership and central planning to a market economy with the dominance of private property. At that time, the issues of ethical regulation of the economics were at a periphery of attention for both the new businesses as well as for the state authorities. It was generally assumed that the legislative framework is a sufficient normative regulator for business in a market economy (Remišová, 1997).

The end of the 90s introduced several changes in the business philosophy. Especially businesses that introduced strategic plans for a long-term development realized that their economics strategy cannot be applied in the unethical business environment and that to reach their objectives, it is necessary to develop and adhere not only to legislative and political frameworks, but also to an ethical framework. Yet, in Slovak environment, the latter was in this era completely absent.

The first ethical mechanism that businesses implemented in order to regulate the employee conduct were corporate codes of ethics. In 1997, the first survey was conducted in Slovakia on codes of conduct, which brought an interesting finding: $18.12 \%$ of the 276 companies had codes of ethics (Remišová, 1998). This result was comparable with the results

1 Act no. 307/2014 on some measures related to the reporting of anti-social activities and on amendments to certain laws, which came into force on the $1^{\text {st }}$ of January 2015. This Act is conventionally known as the Law on whistleblowing. of research carried out at that time in Germany and Switzerland (Ulrich, Lunau \& Weber, 1996), while in Western Europe the business ethics began to develop about ten years earlier, that is in the 80 s of the 20th century, and under considerably different economics circumstances. The crucial impulse to the development of business ethics in Slovakia emerged from business subjects at the mezzo-level of society.

The image of business ethics in Slovakia has significantly changed during the next twenty years. In the academia, the business ethics has become a part of social science research at universities, and today it occupies an important place in the CEE countries. What still appears somehow problematic is the area of teaching business ethics at universities with business and economics focus, because the subject of business ethics is taught mostly only as an optional course. As a pioneering act, we consider the teaching of business ethics at the Faculty of Management at Comenius University in Bratislava, where business ethics is being taught as a compulsory course in master studies since 2015.

In the considered period of the last 25 years, the lack of long-term systematic state and legislative support remains to be the weak point in the development of business ethics in business praxis in Slovakia. Although there is no denying that the government and parliament have taken a number of positive measures in order to combat illegal and antisocial practices in business, for instance, the Act on reporting of antisocial activities, ${ }^{1}$ the legal regulation on criminal liability of legal persons, ${ }^{2}$ some actions against tax evasion and corruption, etc., the state intervention in such an extent and importance like the directives that

${ }^{2}$ At the time of writing this article, the Act on criminal liability of legal persons was adopted by Slovak parliament and signed by the president of the Slovak Republic, with coming into force on the $1^{\text {st }}$ of July 2016. 
have been adopted by the US government known as the Federal Sentencing Guidelines for Organizations, are still unknown in Slovakia.

As aforementioned, the initial development of business ethics in organizations in our country is associated with the adoption of codes of ethics. Praxis has shown that the mere existence of a code of ethics in an organization is not sufficient to guarantee the creation of an ethical organizational culture. Empirical evidence brought ethically sensitive organizations to recognize that in order to have a code of ethics that works effectively, it must be accompanied by a number of other ethical mechanisms and activities that together constitute a comprehensive system. Such a system is in theory labeled as the ethics program of the organization.

In Slovak conditions, the theory of business ethics was confirmed, that ethical issues can be developed only when they become an integral part of the system of organizational management: business ethics has to be planned, organized, people have to be led accordingly, and it must be monitored and assessed continuously.

In our country, we were so far incapable to enforce ethics program as an interconnected set of comprehensive measures to ensure the long-term ethical development of an organization. We assume that the primary cause is that the management of ethics has been in our country a new cultural issue. Businesses in Eastern and Central Europe were disadvantaged in the application of business ethics not only because they were drawn away from the social sciences theory, and not excluding business ethics, but also because they had no experience with the operation of the market and the way of dealing with private ownership and competition, which form the core of the market economy. The vast majority of applied ethics program elements came to the awareness of our theoreticians and practitioners from the theory and praxis in the USA, where business ethics as a science was founded already in the 70s of the 20th century and from there spread to the Western and later also to Eastern Europe. At the risk of mechanical application of the American experience and on the impact of cultural factors on the effectiveness of ethics development in the organization Gary R. Weaver warned in an article from 2001 titled Ethics Program in Global Business: Culture's Role in Managing Ethics. In our conditions, a story is being told about the first Slovak book on business ethics, written by the American philosopher and theologian of Slovak origin, Arnold Luknič. This was the first professional publication on business ethics in Central and Eastern Europe. The book entitled Ethics - The fourth dimension of business was published in 1994 at own expenses of the author. The book referred to a large amount of theoretical knowledge and practical examples and contained a solid list of references. At the time of the issuing of the monograph, however, Slovak professionals and entrepreneurs were not "mentally" prepared for this useful information because this knowledge did not correspond with their experience and understanding. Until 1991 there was no literature in Slovakia in the field of business ethics or even the knowledge that such a form of applied ethics has evolved into a systematic theory. Many theories and practical experiences published in the respective publication got a sense for our readers just a few years later - when the market economy became a reality, and scientific knowledge about the integration of ethics and economics has spread (Remišová, 2015).

\footnotetext{
${ }^{3}$ Luknič refers to the works of Center of Business at Bentley College. Are corporations institutionalizing ethics? In Journal of Business Ethics, 5, 1986, p. 77-89; Dunham, R. B. Organizational behavior. People and processes in management. Homewood, IL, Irwin, 1984; Nichols, M. L., \& Day, v. E. A
}

\section{Current approaches to ethics programs}

There are numerous scientific studies dealing with the issue of implementation of ethics in governance and ethics programs in organizations. However, according to Kaptein studies concentrate usually only on some elements of an ethics program, usually on a code of ethics (Kaptein, 2011) or ethics education (Delaney \& Sockell, 1992; Warren, Gaspar \& Laufer, 2014). Our research is considered to be the first one that monitors the impact of the main formal elements of ethics program onto the ethical thinking of managers from all areas of social life.

Although in Slovak business practice still ethics programs are not widespread purposefully introduced, the very term organizational ethics program (OEP) has been known on the theoretical level for a longer time. It was first used by already mentioned author A. Luknič (1994). According to Luknič, OEP "is established by values, policies, and activities that support the organization's righteous operations. Although not all corporate activities are part of the OEP, their large part has an ethical "charge" (Luknič, 1994, p. 213).

From the academic discourse on OEP, we focused on those issues that we consider to be significant on our research subject. In particular, we noticed that the term OEP is often defined through the enumeration of elements that make it up. Such a practice is obviously linked to the fact that the organizational praxis originated first individual forms of institutionalization of ethics, such as for instance codes of ethics, helpdesks, ethics training, boards of ethics, and ethics officers, whose operations logically required a systematic approach to the development of business ethics in the organization, that is to the adoption of an ethics development program in organization. Metaphorically speaking, the OEP begins by creating the first form of ethics institutionalization. Brenner commented on this that "all organizations have ethics program, but most do not know they do" (Brenner, 1992, p. 391).

Theorists have tried to create a comprehensive picture of the phenomenon by clarifying the structural elements OEP. In the discussion on the OEP components, a strong tradition has the differentiation of OEP to explicit and implicit components. Explicit elements are considered codes of ethics, ethics committees, ethics hotlines, ethics audit, ethics training, educational materials, as well as managerial declarations, decisions of the board of directors, conclusions of the members of boards of ethics, and formalized actions of staff responsible for business ethics in an organization. Implicit OEP elements entail issues like organizational cultures, changes in the organizational structure, incentive systems, and evaluations of behavior, promotion policies, performance appraisal systems, or daily conduct of managers (Luknič, 1994, p. 213-214³).

Some authors differentiate structural and behavioral dimension of OEP components (Brenner, 1992, p. 391), or some others distinguish formal and informal OEP elements (Weaver, Trevino \& Cochran, 1999; de Colle \& Werhane, 2008). The formal ethics program consists of a code of ethics, the ethics committee, ethics communication system, ethics officer or ombudsman, ethics training, and disciplinary processes. Weaver, Trevino, and Cochran (1999) note that formal ethics programs can be conceptualized as organizational control systems aimed at standardizing employee behavior within the domains of ethics and legal

comparison of moral reasoning of a group of individuals on the Defining Issues Test. In Academy of Management Journal, 25, 1982, p. 201-208; Raelin, J. A. The professional as the executives Aide-De-Camp. In Academy of Management Executive, 1, 1987, p. 171-182. 
compliance. Apart from the various terms used to describe OEP components, the substance of its classification remains in our opinion the same - on the one hand there are the elements of an ethics program that arise by institutionalization of ethics into the organization and take the form of specific mechanisms, and on the other hand, there are policies, actions and mental entities implementing the mission of OEP into all processes within the organization (Majluf \& Navarette, 2010; Jose \& Thibodeaux, 1999; Koonmee et al., 2010). Studies on OEP that are concerned with the OEP structure in the framework of such a twodimensional understanding of OEP yielded a number of new OEP research suggestions. However, we think that today it is already insufficient to distinguish only two basic categories of OEP elements because such an approach explains rather insufficiently the essence of the program, whose main mission is to develop business ethics in the organization.

A more complex differentiation is found in Johnson and Abramov (2004, p. 53) who argue that an effective OEP contains the following elements: 1. Standards and procedures to guide member behavior and foster reasonable stakeholder expectations; 2 . Adequate structures and systems that provide for authority, responsibility, accountability, and sustainability; 3. Communication of standards, procedures, and expectations to the enterprise's Members; 4. Programs that monitor and audit member conduct; 5. Encouragement of members to seek advice and report concerns; 6 . Due diligence in hiring, especially for sensitive positions in, for example, management, finance, and contracting; 7. Encouragement of members to follow standards and procedures; 8. Appropriate responses when standards and procedures are violated; 9. Regular evaluations of program effectiveness. Such structuring of the ethics program already reflects the complexity of managing ethics in organizations and helps to create a comprehensive picture of the OEP as a working system.

In our research, we understand OEP as a complex system of logically related ethics assumptions, values, rules, procedures and methods of communication that implement the organization in order to ensure longterm and continuous development of ethics in its organizational culture (Remišová, 2015). Remišová underlines that the core of any ethics program is the code of ethics as a complex of ethics values, standards, and principles that have become a standard of conduct for organizational members. In order these ethics requirements could become true ethical behavior regulators, the organization has to establish transfer channels for their transmission; that is to create an infrastructure for regulation of the conduct of each organizational member. Without such an infrastructure, code of ethics is only a sheer marketing tool. Construction of the infrastructure requires metaphorically speaking, an engine; being it the complete and all-inclusive organizational communication, which aims to transform and promote ethics in every sphere of organizational activity. We consider that the OEP analysis should place greater emphasis on the fact that it is a program that includes a variety of elements - from values, through ethics infrastructure, till enforcement of its ideas into all organizational activities. And we incline to the idea that a particular ethics program consists of the following components (Remišová, 2015):

1. Set of values and ethical requirements (norms, principles).

2. Ethics infrastructure.

3. Forms and means of communication in the organization.

\footnotetext{
${ }^{4}$ The literature distinguished between two bases of such control - the compliance basis and the value basis. The idea of OEP orientation on compliance and values is presented by Weaver and Trevino in their work from 1999. Based on research results they conclude that value-driven OEP has more benefits than compliance-
}

This approach to OEP correlates with our understanding of OEP as a comprehensive system of regulation of conduct and dissemination of ethics in the organization, as opposed to prevalent and relatively popular understanding of OEP as a control system (Weaver, Trevino \& Cochran, 1999; Stansbury \& Barry, 2007; Kaptein, 2009, 2014). ${ }^{4}$

In our research, we aimed to study the impact of structural (formal) OEP components on the ethical thinking of managers. When defining the structural elements of OEP we derived especially from the works of authors Wieland (1993), Joseph (2002), Weber and Fortun (2005), Ulrich, Lunau, and Weber (1996), Jose and Thibodeaux (1999), Weaver, Trevino and Cochran (1999), Johnson and Abramov (2004), Maak and Ulrich (2007), Kaptein (2009, 2014), Koonmee et al. (2010), Majluf and Navarette (2011), as well as from works and practical experiences with the application of business ethics in Slovakia by Remišová (1998, 2011a, 2011b, 2015).

For easier orientation in a large number of formal OEP elements we considered to be it more effective to divide them into five main categories (Remišová 2011b, 2015); each of these categories contains separate forms of institutionalization of ethics, as shown in Table 1.

Table 1: Formal elements of ethics program in organization

\begin{tabular}{|c|c|c|c|c|}
\hline \multicolumn{4}{|c|}{ Forms of ethics institutionalization in organization } \\
\hline $\begin{array}{c}\text { Documents } \\
\text { and } \\
\text { written } \\
\text { materials }\end{array}$ & $\begin{array}{c}\text { Information } \\
\text { channels }\end{array}$ & $\begin{array}{c}\text { Subjects } \\
\text { and bodies }\end{array}$ & $\begin{array}{c}\text { Education } \\
\text { forms }\end{array}$ & $\begin{array}{c}\text { Control } \\
\text { mechanisms }\end{array}$ \\
\hline $\begin{array}{c}\text { Code of } \\
\text { ethics }\end{array}$ & $\begin{array}{c}\text { Hotlines } \\
\text { (boxes, the } \\
\text { internet) }\end{array}$ & $\begin{array}{c}\text { Ethics } \\
\text { council }\end{array}$ & $\begin{array}{c}\text { Seminar } \\
\text { on ethics }\end{array}$ & $\begin{array}{c}\text { Ethics } \\
\text { monitoring }\end{array}$ \\
\hline $\begin{array}{c}\text { Ethical } \\
\text { leitmotiv }\end{array}$ & $\begin{array}{c}\text { Ethics } \\
\text { roundtables }\end{array}$ & $\begin{array}{c}\text { Ethics } \\
\text { director }\end{array}$ & $\begin{array}{c}\text { Seminar } \\
\text { section on } \\
\text { ethics }\end{array}$ & $\begin{array}{c}\text { Ethics } \\
\text { control }\end{array}$ \\
\hline & $\begin{array}{c}\text { Ethics } \\
\text { forums }\end{array}$ & $\begin{array}{c}\text { Ethics } \\
\text { officer }\end{array}$ & $\begin{array}{c}\text { Ethics } \\
\text { workshop }\end{array}$ & $\begin{array}{c}\text { Personal } \\
\text { talks on } \\
\text { ethics }\end{array}$ \\
\hline & Ombudsman & $\begin{array}{c}\text { E-learning } \\
\text { activities }\end{array}$ & \\
\hline & Ethics & $\begin{array}{c}\text { Ethics } \\
\text { advisory } \\
\text { column }\end{array}$ & \\
\hline
\end{tabular}

Source: Remišová, 2011b, p. 71

Which of the forms of institutionalization of business ethics will become indeed a component of the ethics program of any particular organization depends on the specific social, economic, political and cultural factors, in which the organization operates, further on its economic situation, field of activity, size, organizational culture, quality of management, and also on demographic and the educational background of employees (Brenner, 1992; Trevino \& Weaver, 2001; Kaptein, 2009).

Next part of the paper refers briefly to research design and methodological background of our study of the perceived impact of

based ethics program: „In general, a values orientation makes a greater unique contribution to the measured outcomes when compared to a compliance orientation“ (Weaver \& Trevino, 1999, p. 315). 
selected formal OEP elements on the ethical thinking of Slovak managerial personnel.

\section{Research methodology}

This study is part of a broader designed research on ethical leadership and other relevant managerial ethics issues in Slovakia (see Remišová et al., 2015). The sample consisted of 810 Slovak managers working at different levels of management (25.8\% of the sample was populated by top managers, $36.2 \%$ of middle managers, and $35.2 \%$ by low-level managers). As for other demographic characteristics, most of the respondents occupied the managerial position for a relatively long time; $38.4 \%$ of them worked as managers for more than 10 years, and $37 \%$ of the sample was active in a management positions from three to ten years. Nearly $22 \%$ of respondents had served in a managerial position for less than three years. As for their educational background, $6.2 \%$ of respondents had high school education, $13.1 \%$ had bachelor university degree, $66.8 \%$ had earned a master degree, and $12.1 \%$ completed doctoral studies at universities. Further, nearly $60 \%$ of the sample studied economics- or management-oriented study programs at universities and $53.5 \%$ of them indicated that they had attended at least once during their professional career an ethics training course offered by their employers. The majority of the sample (73\%) was in the age cohort of $27-49$ years, $15.6 \%$ at the age of $50-62$ years, $7.3 \%$ was $18-26$ years old, and $2.3 \%$ of the sample population had more than 62 years. As for the gender, $40.2 \%$ of the sample was populated by women.

We derived from a premise that the more OEP elements work in the organization, the greater the development of business ethics in its organizational culture (Kaptein, 2009). However, managers can apply various OEP elements only if they know them and consider them as suitable for shaping and influencing their ethical awareness and ethical orientation. We assume that a purposeful introduction of OEP will become a trend in the future development of business ethics in Slovak business praxis.

Our main objective was to determine which of the formal elements of an ethics program utilized and suitable in Slovak business environment, managers consider being appropriate, i.e. applicable factor for the formation of their ethical orientation. Our research focused on eleven elements of ethics program that respondents evaluated based on their capability to foster the ethical development of managerial personnel. Their responses were classified into three response categories, namely "the element is suitable for the development of ethical thinking of managerial personnel," "the element is not suitable for the development of ethical thinking of managerial personnel", and "I do not know whether the element is or is not suitable". Respondents were asked to evaluate the following elements of an ethics program:

Functioning code of ethics.

- System of reporting mechanisms that ensures reporting of a code of ethics violations.

- The system of regular control of adherence to code of ethics.

- A regular solution of case studies focused on ethics at workplace.

Regular ethics training at the workplace.

- Regular ethics workshops at the workplace.

- Regular ethics roundtables focused on resolution of ethics issues at the workplace.

- Permanent opportunity to consult ethical issues with an external expert on ethics.

- Permanent opportunity to consult ethical issues with an ethics council.
- Permanent opportunity to consult ethical issues with an ethics director.

- Permanent opportunity to consult ethical issues with an ethics officer.

We posed three research questions:

1. Which of the ethics program elements Slovak managers perceive as being suitable for fostering managerial ethical thinking?

2. And vice versa, which of the elements of an ethics program are perceived by Slovak managers as being not suitable for fostering managerial ethical thinking?

3. Which category of ethics program components are the most and the least suited for the development of managerial ethical thinking according to Slovak managers?

\section{Research results}

Table 2 shows the research results on the perceived suitability of eleven ethics program components for fostering managerial ethical thinking from Slovak managers' point of view:

Table 2: Results Summary

\begin{tabular}{|c|c|c|c|}
\hline $\begin{array}{c}\text { Element of ethics program in } \\
\text { organization }\end{array}$ & $\begin{array}{l}\text { Suitable } \\
\text { (in \%) }\end{array}$ & $\begin{array}{l}\text { Not } \\
\text { suitable } \\
\text { (in \%) }\end{array}$ & $\begin{array}{l}\text { Don't } \\
\text { know } \\
\text { (in \%) }\end{array}$ \\
\hline Functioning code of ethics & 89.32 & 1.43 & 9.25 \\
\hline $\begin{array}{l}\text { System of reporting mechanisms } \\
\text { that ensures reporting of code of } \\
\text { ethics violations }\end{array}$ & 73.92 & 10.76 & 15.32 \\
\hline $\begin{array}{l}\text { System of regular control of } \\
\text { adherence to code of ethics }\end{array}$ & 70.42 & 10.87 & 18.71 \\
\hline $\begin{array}{l}\text { Regular solution of case studies } \\
\text { focused on ethics at workplace }\end{array}$ & 62.22 & 10.58 & 27.20 \\
\hline $\begin{array}{l}\text { Regular ethics training at } \\
\text { workplace }\end{array}$ & 62.17 & 18.16 & 19.67 \\
\hline $\begin{array}{l}\text { Regular ethics workshops at } \\
\text { workplace }\end{array}$ & 63.98 & 15.99 & 20.03 \\
\hline $\begin{array}{l}\text { Regular ethics roundtables focused } \\
\text { on resolution of ethical issues at } \\
\text { workplace }\end{array}$ & 60.68 & 15.83 & 23.49 \\
\hline $\begin{array}{l}\text { Permanent opportunity to consult } \\
\text { ethical issues with an external } \\
\text { expert on ethics }\end{array}$ & 47.79 & 19.42 & 32.79 \\
\hline $\begin{array}{l}\text { Permanent opportunity to consult } \\
\text { ethical issues with an ethics } \\
\text { council/committee }\end{array}$ & 36.92 & 23.64 & 39.44 \\
\hline $\begin{array}{l}\text { Permanent opportunity to consult } \\
\text { ethical issues with an ethics } \\
\text { director }\end{array}$ & 36.16 & 23.01 & 40.83 \\
\hline $\begin{array}{l}\text { Permanent opportunity to consult } \\
\text { ethical issues with an ethics officer }\end{array}$ & 62.64 & 12.20 & 25.16 \\
\hline
\end{tabular}

Source: Research

As far as codes of ethics are concerned, we were interested in managers' opinion of functioning codes of ethics, i.e. we wanted our respondents to distinguish between functioning and lively codes of ethics that do serve as regulators of behavior and those that were adopted only for marketing purposes. A functioning code of ethics was considered as the most influential factor to foster managerial ethical thinking by $89.32 \%$ respondents. On the second and third positions were placed a system of reporting mechanisms that ensures reporting of the code of ethics violations $\left(73.92 \%, 2^{\text {nd }}\right.$ place) and system of regular control of 
adherence to the code of ethics $\left(70.42 \%, 3^{\text {rd }}\right.$ place $)$. As the next were placed regular ethics workshops in the workplace $\left(63.98 \%, 4^{\text {th }}\right.$ place), permanent opportunity to consult ethical issues with an ethics officer $\left(62.64 \%, 5^{\text {th }}\right.$ place). More than a half of respondents consider as suitable factors for fostering managerial ethical thinking also regular educational activities such as a solution of case studies ${ }^{5}$ Focused on ethics $(62.22 \%$, $6^{\text {th }}$ place), training focused on ethics in the workplace $\left(62.17 \%, 7^{\text {th }}\right.$ place) and ethics roundtables focused on resolution of ethical issues at the workplace $\left(60.68 \%, 8^{\text {th }}\right.$ place). The last places in the order of factors enhancing managerial ethical thinking were taken by elements, which belong to the sphere of subjects and bodies of institutionalization of business ethics. Possibility to consult ethical issues with an external ethics professional was marked as suitable factor by $47.79 \%$ of respondents $\left(9^{\text {th }}\right.$ place $)$, and only $36.92 \%$ of respondents $\left(10^{\text {th }}\right.$ place $)$ acknowledges this quality to possibility to consult ethical issues with an ethics council or committee, and $36.16 \%\left(11^{\text {th }}\right.$ place) to possible consultations with an ethics director.

We find it very positive that each of the eleven given factors was marked by minimum $36.16 \%$ of managers. We can state, that at least one-third of all managers positively and comprehensively perceives the impact of individual components of OEP on managerial ethical thinking.

During the data analysis, we have found out that the eleven researched elements have sequenced into three basic groups (see Table 3). There are only slight quantitative differences in the responses within each group; on the other hand, when comparing the mean values of overall responses to the three possible answers, the differences between groups are noticeable. The groups are as follows:

1. Formal behavior regulators

2. Educational activities

3. Subjects and bodies managing the ethics development

Table 3: Sequence of OEP elements

\begin{tabular}{|c|l|c|c|c|}
\hline Rank & \multicolumn{1}{|c|}{ OEP group } & $\begin{array}{c}\text { Suitable } \\
\text { (mean } \\
\text { value in } \\
\text { \%) }\end{array}$ & $\begin{array}{c}\text { Not } \\
\text { suitable } \\
\text { (mean } \\
\text { value in } \\
\text { \%) }\end{array}$ & $\begin{array}{c}\text { Don't } \\
\text { know(mean } \\
\text { value in \%) }\end{array}$ \\
\hline 1. & $\begin{array}{l}\text { Formal behavior } \\
\text { regulators }\end{array}$ & 77.89 & 7.69 & 14.42 \\
\hline 2. & $\begin{array}{l}\text { Educational } \\
\text { activities }\end{array}$ & 62.26 & 15.14 & 22.60 \\
\hline 3. & $\begin{array}{l}\text { Subjects and } \\
\text { bodies managing } \\
\text { the ethics } \\
\text { development }\end{array}$ & 45.88 & 19.57 & 34.55 \\
\hline
\end{tabular}

Source: Research

As shown in Table 3, codes of ethics together with measures that directly guarantee its functionality (i.e. control system and reporting mechanisms) have received the highest mean value for suitability as factors that positively affect managerial ethical thinking (77.89\%). The mean values for response category "not suitable" for this group (7.69\%), as well as the mean value of "not knowing" whether these factors positively affect managerial ethical thinking $(14.42 \%)$ were the lowest of all groups. The group was named formal behavioral regulators as together they form a basis for regulating employees' behavior within an organization.

The second grouping of OEP factors was formed by different types of educational activities - workshops, training lectures, roundtables, case studies. The mean score for describing these activities as suitable to foster managerial ethical thinking was $62.26 \%$, and similarly, they took second place in both "I do not know" (15.14\%) and "not suitable" (22.60 $\%)$ response categories.

The third group of factors consisted of subjects and bodies managing the ethics development, i.e. ethics director, ethics officer, ethics council/committee, and external expert on ethics. This group scored lowest in all three response categories; $45.88 \%$ of respondents considered these elements "suitable" for fostering managerial ethical thinking, $19.57 \%$ considered them "not suitable", and $34.55 \%$ of respondents did not know whether they can contribute to enhancing ethical thinking.

\section{Discussion}

The fact, which codes of ethics were dominating factors influencing the ethical thinking of Slovak managers, is not surprising. The codes of ethics belong to the most well-known and the most spread forms of ethics institutionalization (Ulrich, Lunau \& Weber, 1996; Majluf \& Navarrete 2007; Ferrel \& Gresham 1985; Koonmee et al., 2010).

As is known, code of ethics represents basic and binding ethical orientation for every member of an organization. In medium and large enterprises, it is not possible to develop ethics without codes of ethics. Therefore, it is relevant to call this document a backbone of an entire ethical program of an organization. The fact that managers in Slovakia have sufficient knowledge about codes of ethics and their function is reflected in the lowest percentage of answers in the response categories "not suitable" (1.43\%) and "I do not know" (9.25\%).

Even though the code of ethics is an inevitable tool for long-time development of ethics in the organization, it is not the only precondition for it. If codes of ethics were not accompanied by other forms of institutionalization of ethics, and if ethics infrastructure did not develop within a company, the code of ethics would only be a non-functional document. Implementing the code of ethics into organizational culture requires several mechanisms, which control, whether ethical demands given in the code of ethics are respected and define procedures and processes, how employees can report its violation. The results of our research seem to be pleasant as the other forms suitable to foster ethical thinking of managers, which were placed on the second and the third position, were "system of reporting mechanisms that ensures reporting of code of ethics violations" and "system of regular control of adherence to code of ethics".

The reporting and control systems have not only been placed just after the code of ethics in the suitability response category, but their importance is also proved by responses in the area of "not suitable factors" and "I do not know" category. Only $10.76 \%$ of respondents $\left(2^{\text {nd }}\right.$ lowest value) of respondents consider the "system of reporting mechanisms that ensures reporting of the code of ethics violations" as

${ }^{5}$ We categorize ethics case studies as ethics documents; nevertheless, we consider them also as educational OEP components because case studies entail a cognitive element. 
"not suitable" and $15.32 \%$ of respondents ( $2^{\text {nd }}$ lowest value) "does not know". The results of assessing a "system of regular control of adherence to code of ethics" show, that $10.87 \%$ ( $3^{\text {rd }}$ lowest value) of respondents believes this factor is "not suitable" and $18.71 \%\left(3^{\text {rd }}\right.$ lowest value) "does not know" whether it is suitable or not.

Permanent opportunity to consult ethical issues with an ethics officer was marked as the suitable factor influencing managerial ethical thinking by $62.64 \%$ of respondents. Ethics officer is an internal staff member, who is a part of ethics program of an organization. It is an employee whose responsibility is to solve ethical problems. Often, this person is also responsible for compliance. Such working positions are quite new in Slovakia; they have no longer tradition than 5-10 years. Therefore, we consider this research result as very important, in particular for university education in the area of business and managerial ethics. In Slovakia, systematic preparation of business ethics managers (or compliance managers) as it is in the USA, is completely missing.

The majority of our respondents considered various forms of education and discussion on ethical issues at the workplace to be "suitable factors" influencing the ethical thinking of managers. That proves that managers are familiar with these forms of institutionalization of ethics and they consider them as valid methods for developing the level of their ethical orientation. All educational activities were assessed as "suitable" for enhancing ethical thinking of managers ranging from $60.68 \%$ to 63.98 $\%$ respondents.

As far as "not suitable" factors for the development of managerial ethical thinking is concerned, managers answered following: regular round tables were marked by $15.83 \%$ of respondents, proper ethics workshops by $15.99 \%$, and regular ethics training by $18.16 \%$ of respondents.

Despite this, quite surprising is, that almost one-fifth of respondents did not know, whether these are or are not suitable factors influencing ethical thinking of managers, particularly at round tables it was $23.49 \%$ of managers at workshops $20.03 \%$, at training $19.67 \%$, what could suggest, that respondents are not familiar with given educational activities. We come out of a premise that each manager knows, what educational activities are, but not every manager might know, what educational activities "focused on ethics" are. If our suggestion were right, then it would be alarming, that almost one-fifth of all managers would not have the opportunity to take part in ethical education in their organizations.

Among the least, suitable factors for fostering managerial ethical thinking subjects and bodies managing ethics development were marked by our respondents, particularly ethics council/commission and ethics director. Permanent opportunity to consult ethical issues with ethics council or commission was marked as "suitable factor" by only $36.64 \%$, and the opportunity to discuss ethical issues with ethics director by $36.16 \%$ of respondents. This was also confirmed by the results of the "do not know" response category to subjects and bodies managing ethics development. The percentage of respondents, who were not able to assess whether ethical elements belonging to this group are or are not suitable, was the highest of all, as $40.83 \%$ of respondent chose "I do not know" when assessing ethics director, $39.44 \%$ for ethics council/commission, and $32.79 \%$ of respondents did not know whether external ethics professional is or is not useful for enhancing managerial ethical thinking. The results suggest that more than one-third of our respondents might not know or be familiar with these forms of ethics institutionalization. It is especially valid for this field that experience from one country cannot be mechanically transferred to another one (Weaver, 2001).

The positive surprise was also the result of a factor "permanent opportunity to consult ethical problems with an external expert on ethics", which is almost by a half $(47.79 \%)$ of respondents considered as a suitable factor for enhancing ethics awareness. Having the opportunity to consult external experts on ethics is not usual in Slovak business environment. Partly it is because there are not very many professionals on business ethics, but also because organizations are not "mentally" prepared to speak up about their ethical problems outside their company. However, experience with this form of application of business ethics on the organizational level is positive (Remišová, 2011, 2015).

\section{Sequences of formal OEP elements from the perspective of their significance for managerial ethical thinking}

The first three factors in the list of ethical elements that have positive impact on managerial ethical thinking, as well as, low percentage of respondents who were either not able to assess their suitability or marked these factors as not suitable for development of managerial ethical thinking suggest that managers in Slovakia have sufficient knowledge about how to achieve the functionality of the codes of ethics. We deduce it from the fact that factors, which make the functionality of code of ethics possible (i.e. system of reporting mechanisms that ensures reporting of code of ethics violations and system of regular control of adherence to code of ethics) received the highest mean value in the category of suitable factors for enhancing managerial ethical thinking $(77.87 \%)$, the mean value for the "not suitable" response category was $7.69 \%$, and for the "do not know" category it was $14.42 \%$.

Educational activities and ethical discussions represent the second most important group from the perspective of the significance for developing managerial ethical thinking in the Slovak business environment. The group consists of ethics workshops, ethics training, regular ethics roundtables focused on solving relevant ethical issues at the workplace, and ethics case studies. The mean value for describing educational activities as suitable to develop managerial ethical thinking was 62.26 $\%$, and similarly, they took second place in both "I do not know" $(15.14 \%)$ and "not suitable" $(22.60 \%)$ response categories. These findings are positive, as they indicate that managers acknowledge and recognize educational education and permanent discussions about ethical issues as inevitable factors for ethical development.

Discussion about ethical issues is only possible in organizations with open organizational culture, where no one is sanctioned for an uttered opinion. Ethical dialogues and discussions are demanding on character qualities of discussants, as ethical issues are linked to personal integrity, and any kind of questioning personal ethics is perceived sensitively.

The group of factors with the mean value of $44.88 \%$ for being perceived as suitable for enhancing managerial ethical thinking consisted of subjects and bodies managing the ethics development, i.e. ethics director, ethics officer, ethics council/committee, and external expert on ethics. This group scored adequately low in the other two response categories with only $19.57 \%$ of respondents considering these factors "not suitable", and $34.55 \%$ not knowing whether factors included in this group do contribute to enhancing ethical thinking or not.

When assigning these phenomena to the list of factors affecting the ethical thinking and orientation of managers, we were aware that these phenomena are little known in our economic and cultural environment. 


\section{Conclusions}

The analysis of our research results on the perceived impact of 11 elements of organizational ethics program on fostering managerial ethical thinking, based on questioning 810 Slovak managers, led us to the following conclusions:

- Code of ethics is considered by respondents as the most important factor, which fosters ethical thinking of managers.

- We have assumed that there our respondents would acknowledge positive impact of educational activities on ethical thinking of managers. However, even though the positive impact of each educational activity was recognized by at least $60 \%$ of our respondents, the research results also exposed that on average; more than one-fifth of the respondents were not able to decide whether these activities are or are not suitable factors for developing ethical thinking of managers.

- The sequence of formal OEP elements from the perspective of their significance for enhancing managerial ethical thinking is as follows: 1. Formal behavior regulators; 2. Educational Activities; and 3. Subjects and bodies are managing the ethics development. As the least suitable factors were considered mechanisms from category subjects and bodies managing ethics development of an organization, such as ethics director, ethics council/committee, and external expert on ethic. (Ethics officer was the only exception from this group that received a better score.)

- Taking into account a short history of business ethics development in practice, we consider it significant that at least one-third of respondents assessed all 11 OEP elements as suitable for enhancing ethical thinking of managers.

The research results clearly showed that managers in the Slovak business environment perceive OEP elements as factors that have the positive impact on developing managerial ethical thinking. These results are positive as they suggest there is an increased possibility to apply this knowledge in managerial decision-making and acting.

The main result of our research is the recognition that organizations with ethics program have a greater ability to shape the ethical thinking of their managers than those organizations that either do not have any ethics program or apply only some of its elements.

Our results correlate with results of international studies on the topic. They also complement the mosaic of knowledge about the impact of individual factors of organizational ethics program on ethics development within an organization. Kaptein (2014) found out that unethical behavior occurs less frequently in organizations that have an ethics program than in organizations that do not have one. Kaptein researched the relationship between the number of components adopted and the frequency of observed unethical behavior and found out that the most appropriate sequence for adopting components of an ethics program is as follows: 1. A code of ethics; 2. Ethics training and communication; 3 . Accountability policies; 4. Monitoring and auditing; 5. Investigation and correction policies; 6. Ethics office(r); 7. Ethics report line; and 8. Incentive policies. Although our research dealt with formal components of OEP only, (i.e. components 3 and 8 of Kaptein's research were not included in it), it clarifies that ethics program components belong to the positive preconditions for ethical behavior within an organization.
We believe that our research has both theoretical and methodological significance. The methodology can be helpful in further research on organizational ethics programs, as well as organizational ethical development in general. Our knowledge and experience from developing business ethics in specific economic and social conditions (in CEE countries) complement the mosaic of knowledge of developing business ethics on the mezzo-level.

\section{Limitations}

One of the main limiting factors of our research is that we cannot derive from the responses of our respondents whether they have an experience with researched OEP components or not. Therefore, we cannot be sure whether their responses are built upon their own experience or theoretical knowledge, or whether they responded randomly.

The next limitation lies in a fact that knowledge of ethics does not necessarily come hand in hand with ethical behavior of a manager. At this point, we are touching upon managerial integrity in his personal and professional life. Anyway, we consider ethics knowledge to be an inevitable, although not sufficient, the precondition for ethical leadership.

The limitation of our research also lies in the size of our sample. In the initial phases of our research, we have aspired to gain a representative sample of managers working in the Slovak business environment. However, our financial and human resources available were not sufficient to meet this aspiration. ${ }^{6}$

\section{References}

- Brenner, S. N. (1992). Ethics programs and their dimensions. Journal of Business Ethics, 11, 391-399, CrossRef

- Colle, S. de, \& Verhane, P. H. (2008). Moral motivation across ethical theories: What can we learn for designing corporate ethics programs? Journal of Business Ethics, 81, 751-764, CrossRef

- Delaney, J. T., \& Sockell, D. (1992). Do company ethics programs make a difference? An empirical analysis. Journal of Business Ethics, 11, 719-727, CrossRef

- Ferrell, O. C., \& Gresham, L. G. (1985). A contingency framework for understanding ethical decision making in marketing. Journal of Marketing, 49(3), 87-96, CrossRef

- Johnson, K. W., \& Abramov, I. Y. (2004). Business ethics. A manual for managing a responsible business enterprise in emerging market economies. Washington, D.C.: U.S. Department of Commerce. International Trade Administration.

- Jose, A., \& Thibodeaux, M. S. (1999). Institutialization of ethics. The perspective of managers. Journal of Business Ethics, 22(2) 133-143, $\underline{\text { CrossRef }}$

- Joseph, J. (2002). Integrating business ethics and compliance programs: A study of ethics officers in leading organizations. Business and Society Review, 107(3), 309-347, CrossRef

- Kaptein, M. (2009). Ethics programs and ethical culture: A next step in unravelling their multi-faceted relationship. Journal of Business Ethics, 89, 261-281, $\underline{\text { CrossRef }}$

- Kaptein, M. (2011). Understanding unethical behavior by unraveling ethical culture. Human Relations, 64, 843-869, $\underline{\text { CrossRef }}$
6 This article was presented at the international conference Global Connectivity, Knowledge and Innovation for Sustainability and Growth: New Paradigms of Theory and Practice, Montclair, NJ in June 2016 and was included in the Atal,
V., \& Dubey, R. S. (Eds.). Proceedings of the $14^{\text {th }}$ International Conference of the Society for Global Business \& Economic Development (SGBED), Montclair, NJ, 2016 (pp. 742-754). 
- Kaptein, M. (2014). The effectiveness of ethics programs: The role of scope, composition, and sequence. Journal of Business Ethics. DOI 10.1007/s10551-014-2296-3, CrossRef

- Koonmee, K., Singhapakdi, A., Virakul, B., \& Lee, D.-J. (2010). Ethics institutionalization, quality of work life, and employee jobrelated outcomes: A survey of human resource managers in Thailand. Journal of Business Research, 63, 20-26, CrossRef

- Luknič, A. (1994). Štvrtý rozmer podnikania - etika. Bratislava: SAP.

- Maak, T., \& Ulrich, P. (2007). Integre Unternehmensführung. Ethisches Ortientierungswissen für die Wirtschaftspraxis. Stuttgart: Schäffer-Poeschel Verlag.

- Majluf, N. S., \& Navarrete, C. M. (2011). A two-component compliance and ethics program model: An empirical application to Chilean corporations. Journal of Business Ethics, 100, 567579, CrossRef

- Remišová, A. (1997). Podnikatel'ská etika. Úvod do problematiky. Bratislava: Ekonóm.

- Remišová, A. (1998). Etické kódexy. Bratislava: Ekonóm.

- Remišová, A. (2011a). Etika a ekonomika. Bratislava: Kalligram.

- Remišová, A. (2011b). Vademékum podnikatel'skej etiky. Vademecum of Business Ethics. Bratislava: Sprint dva.

- Remišová, A. (2015). Súčasné trendy podnikatel’skej etiky - od teórie k praxi. Bratislava: Wolters Kluwer.

- Remišová, A., Lašáková, A., Rudy, J., Sulíková, R., Kirchmayer, Z., \& Fratričová, J. (2015). Etické vedenie l'udí v slovenskom podnikatel'skom prostredí. Bratislava: Wolters Kluwer.

- Stansbury, J., \& Barry, B. (2007). Ethics programs and the paradox of control. Business Ethics Quarterly, 17(2), 239361.Trevino, L. K., \& Weaver, G. R. (2001). Organizational justice and ethics program ,follow-through “: Influences on employees' harmful and helpful behaviour. Business Ethics Quarterly, 11(4), 651-671, CrossRef

- Ulrich, P., Lunau, Y., \& Weber, T. (1996). ,Ethikmassnahmen“ in der Unternehmenspraxis. Zum Stand der Wahrnehmung und Institutionalisierung von Unternehmensethik in schweizerischen und deutschen Firmen. Ergebnisse einer Befragung. Beiträge und Berichte, 73, St. Gallen: Institut für Wirtschaftsethik an der Universität.

- Warren, D. E., Gaspar, J. P., \& Laufer, W. S. (2014). Is formal ethics training merely cosmetic? A study of ethics training and ethical organizational culture. Business Ethics Quarterly, 24(1), 85-117, $\underline{\text { CrossRef }}$

- Weaver, G. R. (2001). Ethics programs in global businesses: Culture's role in managing ethics. Journal of Business Ethics, 30 , 3-15, CrossRef

- Weaver, G. R., \& Trevino, L. K. (1999). Compliance and values oriented ethics programs: Influences on employees' attitudes and behaviour. Business Ethics Quarterly, 9(2), 315-335, CrossRef

- Weaver, G. R., Trevino, L. K., \& Cochran. P. L. (1999). Corporate ethics practices in the mid-1990's: An empirical study of the Fortune 1000. Journal of Business Ethics, 18, 283-294, CrossRef

- Weber, J., \& Fortun, D. (2005). Ethics and compliance officer profile: Survey, comparison, and recommendations. Business and Society Review, 110(2), 97-115, CrossRef

- Wieland, J. (1993). Formen der Institutionalisierung von Moral in amerikanischen Unternehmen. Die amerikanische Business-
Ethics-Bewegung: Why and how they do it. Bern: Stuttgart; Wien: Haupt. 